\title{
Ideal Evaluation in Islamic Education Learning
}

\author{
Siti Kholidatur Rodiyah \\ Universitas Sunan Giri Surabaya \\ kholidaturrodiyah@gmail.com
}

\begin{abstract}
A prospective teacher will actually be demanded by professionals in carrying out their duties as an educator. In teaching later a teacher is required to be able to provide the best education so as to achieve the desired educational goals. Evaluation in Islamic education the way or technique of assessment of student behavior based on a comprehensive standard calculation of all aspects of mental psychological and spiritual life of students. Because the personal figure desired by Islamic education is not only a person who is religious in nature, but also has the knowledge and skills that are capable of doing charity and worshiping God and society. In that case, educational evaluation is one part of the activities carried out by a teacher to support the achievement of educational goals, and among evaluations conducted by the teacher is the evaluation of learning outcomes, where the evaluation is carried out to measure the extent of students' knowledge and skills after receive material and direction from a teacher.Evaluation of learning outcomes is very important where a teacher must be truly objective and professional in implementing it, because on the side of a teacher will decide the success or failure of a student.
\end{abstract}

Keyword : Ideal Evaluation, Islamic Education Learning, Teacher

\section{DISCUSSION}

\section{Definition of Evaluation of PAI Learning}

Etymologically, "evaluation" comes from the word"to evaluate" which means "to evaluate". Evaluation of religious education is an activity to determine the level of progress of a job in religious education. Evaluation is a tool to measure the extent to which students' mastery of education has been given (Zuhairini, 1993).

What is meant by assessment in education are the decisions taken in the education process in general; both regarding the planning, management, process and followup of education or relating to individuals, groups, and institutions (Armai, 2002). Therefore, what is meant by evaluation in Islamic education is the making of a number of decisions related to Islamic education in order to see the extent of the success of education in harmony with Islamic values as the goal of Islamic education itself. Or in short, what is meant by evaluation here is an evaluation of the teaching and learning process where the teacher interacts with students(Basyirudin, 2002). 


\section{Purpose of Evaluation of PAI Learning.}

The purpose of evaluating learning outcomes in the teaching and learning process (including teaching and learning of religious education): to find out or collect information on the level of development and progress obtained by the judge, in order to achieve the goals set in the curriculum. In addition, the teacher can assess the effectiveness of the experiences and activities that have been carried out while at the same time considering the results as well as the teaching methods and teaching system used whether they are in accordance with what is expected in the curriculum (Zuhairini, 1993).

The purpose of the evaluation is to find out the level of students' understanding of the subject matter, train their courage and invite students to recall the material that has been given. In addition, the evaluation program aims to find out who are among the smart and weak students, so that the weak are given special attention so that they can catch up on their shortcomings, so that they go up, grade and finish school. The aim of evaluation is not only to evaluate students, but also to evaluate the educator, to what extent he is serious in carrying out his duties to achieve the objectives of Islamic education (Choirul Anam, 2014).

\section{PAI Learning Evaluation Function.}

As one important component in the implementation of Islamic education, evaluation functions as follows:

1. To find out how far the effectiveness of teaching and learning that has been done is really right or not, both with regard to the attitudes of educators / teachers and students / students.

2. To find out the results of student achievement in order to determine the decision whether the subject matter needs to be repeated or can be continued.

3. To find out or gather information about the level of development and progress obtained by students in order to achieve the goals set in the Islamic education curriculum.

4. As material for reports for parents of students about student learning outcomes. This report can be in the form of report cards, certificates, certificates, diplomas etc.

5. To compare learning outcomes obtained previously with learning conducted after that, in order to improve education (Armai, 2002).

Prof. Dr. S. Nasution states, that the function of educational evaluation is as follows:

1. Knowing the ability of children, so that the child can be helped to choose a department, school or position in accordance with their talents.

2. Find out to what extent the child is achieving learning and educational goals. 
3. Demonstrate weaknesses and weaknesses of students so that they can be given special assistance to overcome those deficiencies. Students view the test as well as the teacher's attempt to help them.

4. Shows the weaknesses of the teaching methods used by teachers. Student shortages often stem from poor teaching methods. Each test or test is a tool for evaluating the work of students and teachers.

5. Give clearer instructions about the objectives of the lesson to be achieved. Tests or tests give clues to children about what and how children should learn. There is a relationship between the nature of examinations and learning techniques.

6. Encouraging students to study hard, children will be eager to learn if it is known that a test or test will be held.

From these expressions it can be concluded that the function of evaluating learning outcomes in the teaching and learning process of religious education to:

1. Determination of weaknesses and / or strengths and ability of students to have / master religious teaching educational materials that have been received in the teaching and learning process.

2. Determination of components / elements (objectives, materials, tools and methods, etc.), which need to be reviewed and revised / improved

3. Determination of weaknesses / strengths of teachers in implementing teachinglearning programs

4. Guiding the growth and development of students both individually and in groups (Zuhairini, 2002).

\section{Principles of Evaluation of PAI Learning.}

The principles of evaluating religious education are divided into two parts:

1. Basic Principles of Evaluation, the basic principles of evaluation that are commonly termed the idealism principle of evaluation include the following matters:[9]

a. Evaluation is a communication tool; namely communication between and between schools with parents and schools with the community.

b. Evaluation to help children achieve maximum development.

c. The evaluation of the child is not only compared to the value of the child itself in the previous results but also compared to the group.

d. In carrying out the evaluation should use various kinds of evaluation tools or methods with all its variations.

e. Evaluation should give follow up

f. That in giving a value / evaluation someone is based on a state that can be absorbed by the human senses, while the state of one's heart becomes the business of each person with Allah SWT. 
1. Principles of evaluation implementation

In providing an evaluation of learning outcomes in the teaching and learning process of religious education must be based on the principles of implementation. The principles of implementation are as follows:
a. Comprehensive
b. Continuity
c. Objectivity

\section{Kind of Evaluation of PAI Learning.}

Various types of evaluation of learning outcomes in the teaching and learning process of religious education in schools can be divided into:

1. Formative Evaluation Formative

Evaluation is an evaluation carried out after the completion of one topic. Thus the evaluation of short-term learning outcomes. In its implementation in this formative evaluation school is a daily test.

2. Summative

Summative evaluation is an evaluation carried out after several subjects have been completed. Thus summative evaluation is an evaluation of long-term learning outcomes. In practice in schools, if formative evaluations can be equated with daily tests, then summative evaluations can be likened to general tests that are usually carried out at the end of each quarter or the end of the semester.

3. Placement Evaluation

If enough prospective students are accepted at a school so more than one class is needed, then special considerations are needed for distribution. Whether good children will be put together in one class or all classes will be filled with a mixture of good, medium and poor children, information is needed. Such information can be obtained by evaluating placement. This test is conducted at the beginning of the school year to determine the level of student knowledge related to the material that has been delivered.

4. Diagnostic Evaluation

Diagnostic Evaluation is an evaluation that serves to recognize the background of life (psychology, physical and environmental) of students who experience learning difficulties whose results can be used as a basis for solving these difficulties.

And there are four types of evaluations of Islamic education, namely;
a. Formative evaluation
b. Summative evaluation
c. Placement evaluation
d. Diagnostic evaluation 


\section{Assessment Tools.}

In conducting the evaluation of religious teaching and learning outcomes, you will be introduced to three forms of evaluation, namely (Zakiyah, 2015):

1. Written

Is a test, exam or test, which is experienced by a number of students simultaneously and must answer a number of questions or questions in writing within the allotted time. There are two types of written tests, the essay test and the objective test.

2. Oral Tests

If a number of students are verbally tested by one or more examiners.

3. Observation

Is a method / ways to analyze and record systematically about behavior by looking / observing students or groups of students directly. In the context of evaluating learning outcomes, observation is used as an evaluation tool to assess learning activities which are skills or psychomotor aspects.

\section{CONCLUSION}

Definition of Evaluation of Learning Islamic Education. What is meant by evaluation in Islamic education is the making of a number of decisions related to Islamic education in order to see the extent of the success of education in harmony with Islamic values as the goal of Islamic education itself. The purpose of evaluating learning outcomes in the process teaching and learning (including teaching and learning religious education): to find out or collect information on the level of development and progress obtained by the jury, in order to achieve the goals set in the curriculum.

\section{REFERENCES}

Arif, Armai, 2002. " Pengantar Ilmu dan Metodologi Pendidikan Agama Islam”, (Jakarta: Ciputat Press,)

Anam, Choirul, 2014. "Metodologi Pendidikan Agama Islam", (Jombang: Tebuireng,)

Hasan, Basyri dan Beni, Ahmad Saebani, 2010. Ilmu Pendidikan Islam, (Bandung: CV Pustaka Setia,)

Usman, Basyiruddin, 2002. Metodologi Pembelajaran Agama Islam, (Jakarta: Ciputat Pers,)

Zuhairini dkk, 1993." Metodologi Penelitian Agama", (Solo: Ramadhani,) 